\title{
Th-U powered metamorphism: thermal consequences of a chemical hot spot
}

\author{
ALEXANDER De VRIES VAN LeEUWEN ${ }^{1 *}$, MARTIN \\ HAND $^{2}$, LAURA MORRISSEY ${ }^{3}$, TOM RAIMONDO ${ }^{1,3}$
}

${ }^{1}$ School of Natural and Built Environments, University of South Australia, GPO Box 2471, Adelaide, SA 5001, Australia (*correspondence:

alexander.devriesvanleeuwen@unisa.edu.au)

${ }^{2}$ Department of Earth Science, University of Adelaide, Adelaide, SA 5005, Australia

${ }^{3}$ Future Industries Institute, University of South Australia, GPO Box 2471, Adelaide, SA 5001, Australia

High geothermal gradient metamorphism characterised by cordierite- and andalusite-bearing prograde mineral assemblages requires thermally energetic environments that represent significant excursions from normal continental thermal regimes. Heat advected via magmas is typically considered necessary to generate the thermal regimes to stabilise cordierite-andalusite bearing rocks. Therefore, metamorphism should be spatially and temporally associated with magmatism with elevated thermal conditions being transient unless there is temporally sustained magmatism. While this will likely remain the governing paradigm, we present evidence from the northern Flinders Ranges in Southern Australia, where cordierite-andalusite-bearing mineral assemblages are not spatially or temporally associated with magmatism. Our study focusses on cordieritebearing schists from the base of a thick Neoproterozoic sedimentary sequence. These gently deformed strata directly overlie Mesoproterozoic metasediments and granitic rocks whose regional heat production rate is robustly measured to be around $10 \mu \mathrm{Wm}^{-3}$, which is approximately 5 times the global mid-crustal average. We present results from in-situ $\mathrm{U}-\mathrm{Pb}$ monazite geochronology combined with mineral equilibria modelling that show the rocks at the base of the sedimentary succession began to experience amphibolitegrade metamorphism while the sedimentary sequences were still accumulating. Mineral equilibria modelling indicates that metamorphism took place under average geothermal gradient conditions in excess of $180{ }^{\circ} \mathrm{C} / \mathrm{kbar}\left(>48{ }^{\circ} \mathrm{C} / \mathrm{km}\right)$ that propagated to depths of at least $12-14 \mathrm{~km}$. These thermal gradients persisted for upwards of $100 \mathrm{Ma}$, maintained by a lack of crustal erosion, and are documented by long-lived crustal anatexis. This system may be the archetypal example of geochemically powered metamorphism, recording the interplay between chemically extreme basement and thermally insulating sedimentary cover. 